\title{
Environmental Management Long-Term Stewardship Transition Guidance
}

November 2001

Idaho National Engineering and Environmental Laboratory Bechtel BWXT Idaho, LLC 


\title{
Environmental Management Long-Term Stewardship Transition Guidance
}

November 2001

Idaho National Engineering and Environmental Laboratory Idaho Falls, Idaho 83415

\author{
Prepared for the \\ U.S. Department of Energy \\ Office of Environmental Management \\ Under DOE Idaho Operations Office \\ Contract DE-AC07-99ID13727
}




\begin{abstract}
Long-term stewardship consists of those actions necessary to maintain and demonstrate continued protection of human health and the environment after the completion of facility cleanup. Long-term stewardship is administered and overseen by the U.S. Department of Energy Environmental Management Office of Science and Technology. This report describes the background of long-term stewardship and gives general guidance about considerations when ownership and/or responsibility of a site should be transferred to a long-term stewardship program. This guidance document will assist the U.S. Department of Energy in: (a) ensuring that the long-term stewardship program leads transition planning with respect to facility and site areas, and (b) describing the classes and types of criteria and data required to initiate transition for areas and sites where the facility mission has ended and cleanup is complete.
\end{abstract}




\section{CONTENTS}

ABSTRACT iii

ACRONYMS vii

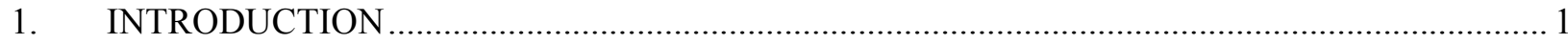

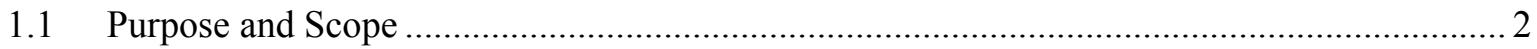

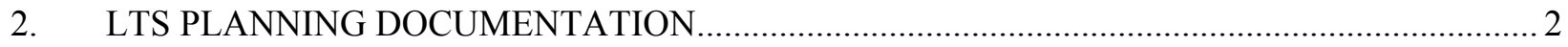

2.1 National Defense Authorization Act Long-Term Stewardship Report ................................. 2

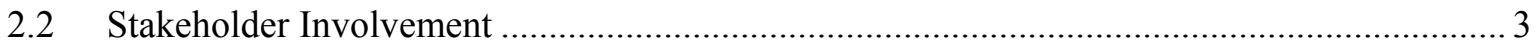

2.2.1 Coordination with Government Agencies .............................................................. 3

3. ENVIRONMENTAL MANAGEMENT LTS PROGRAM …................................................. 4

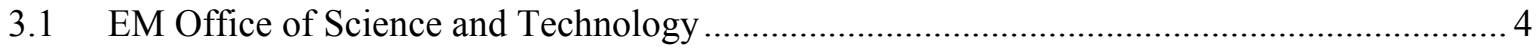



4. MISSION COMPLETION TRANSITION GUIDANCE …................................................. 5

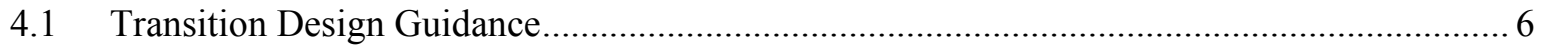

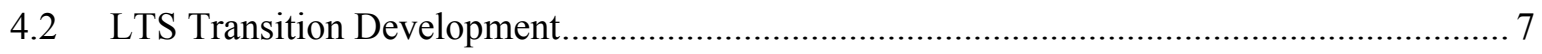

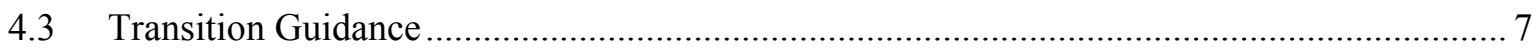

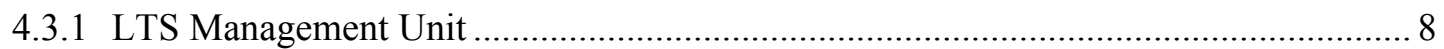

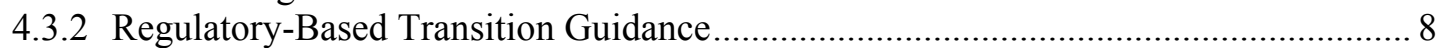

4.3.3 Infrastructure Needs Transition Guidance ......................................................... 9

4.3.4 Data/Information Management-Based Transition Guidance ........................................ 9

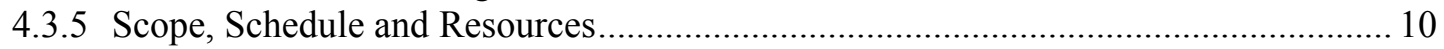

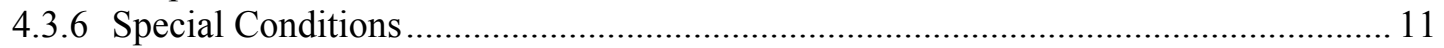

4.3.7 Identification of Long-term Stewardship Transition Guidance .................................. 11

5. RECOMMENDATIONS FOR DEVELOPMENT OF TRANSITION CRITERIA....................... 11

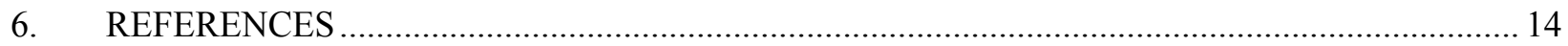

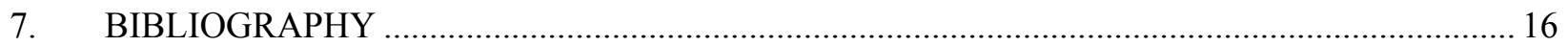

Appendix A-Example Documentation to Identify LTS Transition Criteria 


\section{ACRONYMS}

BRAC Base Realignment and Closure

CCR Construction Completion Report

CERCLA Comprehensive Environmental Response, Compensation, and Liability Act

D\&D decontamination and decommissioning

D\&D\&D deactivation, decontamination, and dismantlement

DOE U.S. Department of Energy

EM Environmental Management

FUSRAP Formerly Utilized Sites Remedial Action Program

GIS geographical information system

INEEL Idaho National Engineering and Environmental Laboratory

LTS long-term stewardship

MOA memorandum of agreement

MOU memorandum of understanding

NHPA National Historic Preservation Act

NDAA National Defense Authorization Act

NEPA National Environmental Policy Act

NRC National Research Council

O\&M operation and maintenance

PSO Program Secretarial Office

RCRA Resource Conservation and Recovery Act

ROD record of decision

SARA Superfund Amendments and Reauthorization Act

TPH total petroleum hydrocarbon 


\section{Environmental Management Long-Term Stewardship Transition Guidance (Draft)}

\section{INTRODUCTION}

For the U.S. Department of Energy (DOE), long-term stewardship (LTS) consists of those actions necessary to maintain and demonstrate continued protection of human health and the environment after DOE has completed facility cleanup. The interest and concern about LTS emerged from DOE's focus on accelerating cleanup and improving management of the cleanup program. As cleanup has progressed at various DOE facilities, the need to prepare and implement post-cleanup LTS plans has also accelerated.

Long-term stewardship is defined as:

"...all activities necessary to ensure protection of human health and the environment following completion of cleanup...includes all engineered and institutional controls designed to contain or to prevent exposure to residual contamination and waste...." (DOE 2001a).

Cleanup is defined as completion of Comprehensive Environmental Response, Compensation, and Liability Act (CERCLA) remediation and/or Resource Conservation and Recovery Act (RCRA) closure and deactivation, decontamination, and decommissioning (D\&D\&D) actions. In Accelerating Cleanup: Paths to Closure (DOE 1998), DOE defines site cleanup as complete when the following criteria have been met:

- Deactivation or decommissioning of all facilities currently in the Environmental Management (EM) Program has been completed, excluding any long-term surveillance and monitoring

- All releases to the environment have been cleaned up to the level specified by the governing regulatory agency

- Groundwater contamination has been contained or long-term treatment or monitoring is in place

- $\quad$ Nuclear material and spent fuel have been stabilized and/or placed in safe long-term storage

- $\quad$ Legacy waste (i.e., waste produced by past nuclear weapons production activities, with the exception of high-level waste) has been disposed in an approved manner.

The DOE considers LTS to be an integral part of decision-making during the remediation process. As such, DOE now requires the preparation of a long-term stewardship plan during the early stage of the cleanup process so that the long-term stewardship technical requirements and costs can be considered during the cleanup process. Sites will need to clearly define the end state (including cleanup levels and land use), and identify and document the scope, schedule, costs, and uncertainties associated with the long-term stewardship activities.

Examples of LTS activities are surveillance, record-keeping, inspections, groundwater monitoring, ongoing pump and treat activities, cap repair, maintenance of entombed buildings or facilities, maintenance of other barriers and containment structures, access control, and posting signs (DOE 2001a). In accordance with CERCLA, contained and capped areas will require regular inspections (as required by the specific records of decision [RODs] for each area), monitoring, and maintenance. The LTS activities 
for deactivated facilities pending final D\&D\&D will include maintaining facility-filtered off-gas systems, preventing and cleaning up contaminant releases, and maintaining surveillance and monitoring.

\section{$1.1 \quad$ Purpose and Scope}

The DOE's EM LTS Program provides the managerial, technical, and scientific expertise needed to oversee the long-term environmental management obligations. The LTS program is currently developing the management structures and plans to complete specific LTS obligations. Efforts are underway to develop policies and systems by which to operate the LTS program. Additionally, the LTS program is supporting nationwide obligations by integrating lessons learned in the administration of local programs.

This document provides guidance for transitioning cleanup sites managed by the DOE EM program to LTS. Any sites that are currently outside of EM that may eventually be transferred an EM LTS program is not addressed by this guidance. Section 4 notes the conditions that must be met as well as the commitments and exchange of information that must occur between the site landlord Program Secretarial Office (PSO) and EM. Section 4.1 reiterates the findings of the National Research Council with respect to principles that DOE must focus on in order to develop and implement effective institutional management plans. Depending upon the size and cleanup complexity of a given site, as well as the nature of any continuing mission, these principles will relate to development and implementation of a sitespecific LTS implementation plan. Section 4.2 provides the concepts and principles related to development of site specific transition criteria, stressing flexibility in criteria and preservation of remediation goals without unwarranted investment in re-remediation or additional funding impacts identified outside of those identified at the time of transition. Without being prescriptive, Section 4.3 provides examples of and expanded discussion on suggested transition criteria to be satisfied prior to initiating transfer to the PSO LTS organization. The LTS transition guidance presented in this document is intended to be general in nature and should be used in conjunction with programmatic and regulatory requirements, which may exist and are already implemented at each site and laboratory in the DOE complex or will be developed in the future.

\section{LTS PLANNING DOCUMENTATION}

Key documents used in the formulation of this guidance were the Idaho National Engineering and Environmental Laboratory (INEEL) Long Term Stewardship Draft Technical Baseline (INEEL 2001), and $A$ Report to Congress on Long-Term Stewardship (DOE 2001a). The LTS planning information was also taken from the Integrated Planning and Accountability Budget System. Many other references were consulted, but not cited, in the development of this document. These references are provided in a bibliography in Section 7.

\subsection{National Defense Authorization Act Long-Term Stewardship Report}

The FY 2000 National Defense Authorization Act Conference Report (House of Representatives 1999) requested that DOE submit to Congress a report on DOE's existing and anticipated LTS obligations at sites where environmental restoration activities are complete or will be complete by 2006. The resulting report, A Report to Congress on Long-Term Stewardship (known henceforth as the Report to Congress) (DOE 2001a), includes sections specific to DOE facilities. The report identifies sites, on a state-by-state basis, for which DOE will have LTS functions. In addition, the reports lists the primary assumptions and planning for LTS, estimated costs for LTS activities to 2070 (by site), facility descriptions, primary contaminant(s) of concern, and cleanup plans and issues for individual waste sites by media (e.g., soil, groundwater, engineered units). All environmental restoration activities under 
CERCLA are discussed. The writers of the Report to Congress used both geographic proximity and similarity of contaminants or cleanup actions to develop the sections on DOE facilities.

\subsection{Stakeholder Involvement}

A commitment to stakeholder involvement has been central to all efforts within the EM planning process. This also will be the case in the development of the LTS plan. The DOE has four goals for involving stakeholders:

1. Inform stakeholders about EM projects

2. Work with stakeholders in understanding changes in the EM work and budget allocations

3. Include stakeholder participation and provide feedback concerning stakeholder interests

4. Involve stakeholders in the LTS strategic planning and implementation.

For programs such as LTS, the individual program typically implements stakeholder involvement, with coordination through the DOE Office of Communications' public involvement coordinator and each site's Communications Department. Stakeholder groups have been, and will continue to be, briefed about and given specific recommendations throughout the LTS planning process. A comprehensive EM listing of stakeholders may be obtained through the applicable DOE Office of Communications for use in this process.

Stakeholders at each site who should receive communication via personal contact or written information include units of government such as local, state, and federal government agencies and elected officials; affected Indian tribes and tribal councils; local and national electronic and print media; the general public; and special interest groups.

\subsubsection{Coordination with Government Agencies}

A commitment to coordinate activities with all involved agencies (especially those involved in remedy selection and implementation) has been central to all efforts within the EM planning process. To maintain regulatory compliance and ensure broad stakeholder involvement, the developers of the LTS plan also will coordinate with these groups. The specific process and procedures to be followed to ensure broad-based agency coordination is currently conducted within the context of the various EM program offices.

The DOE will be responsible for coordinating stakeholder involvement in concert with each site, and for providing copies of any discussion draft prepared in the development of the LTS plan to identified stakeholders. Copies will be provided to other interested parties upon request. The following lists are examples of federal and state agencies that may be considered as stakeholders.

\section{Federal Agencies}

- $\quad$ Defense Nuclear Facilities Safety Board

- Department of Agriculture

- $\quad$ Natural Resources Conservation Service 
- Department of Commerce

- National Oceanic and Atmospheric Administration

- Nuclear Regulatory Commission

- Department of Interior

- $\quad$ Bureau of Land Management

- $\quad$ National Park Service

- $\quad$ Fish and Wildlife Service

- $\quad$ U.S. Geological Survey

- Department of Transportation

- Environmental Protection Agency, Local Region

\section{ENVIRONMENTAL MANAGEMENT LTS PROGRAM}

\subsection{EM Office of Science and Technology}

At the national level, LTS is administered through DOE's EM program. The office responsible for LTS under the EM program is the Office of Science and Technology. The mission statement for the Office of Science and Technology is as follows:

"The mission of the Science and Technology program is to manage and direct a national, solution-oriented science and technology program that provides the scientific foundation, new approaches, and new technologies that bring about significant reductions in risk, cost, and schedule for completion of the EM cleanup mission. Science and Technology provides the full range of science and technology resources and capabilities, from a targeted basic research program through development, demonstration, and deployment and technical assistance needed to deliver and support fully developed, deployable scientific and technological solutions to EM cleanup and long-term stewardship problems. Establishes policy and provides guidance on long-term stewardship to ensure that human health and the environment are protected after cleanup is completed, sites are closed, waste is emplaced for disposal, or facilities are stabilized for long periods awaiting possible future remediation. Also, provides management oversight of DOE's EM laboratories, including institutional planning, policy and processes, and management contracts, to enhance and maintain the overall strength and vitality of the laboratories in contributing to the goals of the EM cleanup program." (DOE Office of Science and Technology 2001).

\subsection{LTS Regulatory Background}

Certain aspects of LTS are mandated by statutes, regulations, compliance agreements, DOE orders and directives, and site-specific documents and policies. However, many LTS actions have yet to be 
defined in the interaction that will occur between DOE, stakeholders, and the various regulatory authorities with roles in the stewardship of the public domain. It is important to recognize, however, that LTS planning and the need for associated transition criteria result from a policy decision as opposed to a legislative mandate. In this regard, DOE's involvement in LTS emerged from the Department's focus on improving the management of accelerated site cleanup programs. In October 1999, DOE published From Cleanup to Stewardship, A Companion Report to Accelerating Cleanup: Paths to Closure and Background Information to Support the Scoping Process Required for the 1998 PEIS Settlement Study (DOE 1999). This report gives substantial background on the anticipated LTS planning activities that will occur across the DOE complex. Further background on LTS and DOE's efforts to address the terms of a December 1998 lawsuit settlement agreement (Natural Resources Defense Council, et al., v. Richardson, et al., Civ. No. 97-936 (SS) (D.D.C.), December 12, 1998) is available in DOE's Report to Congress (DOE 2001a).

Although statutory and regulatory requirements provide important guidance in the formulation of LTS transition criteria, existing mandates designed to control pollution or protect resources do not clearly delineate the full scope of future activities tied to LTS. Additional research, analysis, and coordination of this facet of transition criteria will be necessary to ensure the development of effective LTS implementation strategies.

DOE EM maintains one useful reference tool available for an assessment of regulatory criteria related to LTS at http://lts.apps.em.doe.gov/center/reports/pdf/overview_statutes_regs.pdf (DOE Office of Environmental Management 2001). This web page provides a link to a 20-page collection of "Major Environmental Statutes, Regulations, and Executive Orders for Long Term Stewardship at DOE Sites." The collection is regularly updated through a coordinated effort between DOE's EM Office of LTS and Office Environmental Policy and Guidance.

The website also contains a set of tables that both summarize and link the user to DOE orders, policies, guidance, documents, and official communication relevant to the LTS statutes, regulations, and executive orders. Similarly, other federal policies and guidance pertinent to implementation of LTS are provided. Although a host of additional federal, state, and local authorities may eventually become involved as stakeholders in the LTS planning process, this reference tool only provides hyperlinks to aid in the identification of additional applicable regulations promulgated by the Environmental Protection Agency and Nuclear Regulatory Commission.

Two other important memoranda from the Deputy Secretary of Energy and Assistant Secretary of Environmental Management are available on the web at http://ndep.state.nv.us/lts/biblio.htm\#key (Glauthier 2000; Huntoon 2001; National Governor's Association 2001). These documents require site-specific LTS plans for each DOE facility.

\section{MISSION COMPLETION TRANSITION GUIDANCE}

The interest and concern about LTS emerged in large part from the DOE's focus on accelerating site cleanup and improving management of the cleanup program. As cleanup is accelerated at various DOE facilities, the need to prepare and implement post-cleanup LTS plans and activities is also accelerated. The DOE now considers LTS to be an integral part of decision-making during the site remediation process; however, little guidance exists as to how and when a proposed unit is ready to be transitioned to the LTS program. However, transfer of LTS responsibilities may occur only after the site landlord Program Secretarial Office (PSO) and EM agree that the EM mission at the site has been completed and the following conditions are met per "Long-Term Stewardship Transition to Site Landlord" (Glauthier 2000). 
1. A technical planning document has been developed establishing the current LTS operating baseline and describing the scope and operating costs for future LTS activities.

2. The budget authority and budget target has been transferred to the receiving PSO of the amount equivalent to the operating costs for LTS activities.

3. A formal transfer agreement for the LTS, that includes post-transfer responsibilities, has been coordinated and signed for each site.

\subsection{Transition Design Guidance}

The National Research Council (NRC 2000) recommended that the DOE develop and implement effective institutional management plans that focus on five key principles:

- $\quad$ Plan for uncertainty by anticipating a range of possible outcomes of cleanup strategies and post-remediation institutional management strategies and adding uncertainty by applying uncertainty ranges.

- $\quad$ Plan for fallibility in cleanup strategies and post-remediation institutional management strategies by selected site uses that are less likely to be subject to frequent change, and that information about contaminated sites is preserved and communicated effectively to future site users.

- $\quad$ Develop appropriate and substantive incentive structures, including stable long-term funding structures, access to needed resources, and encourage active citizen oversight of long-term institutional management.

- Undertake scientific, technical, and social research and development, including research and development for contaminant reduction, contaminant isolation, and stewardship measures.

- $\quad$ Plan to maximize follow-through by implementing an iterative, long-term institutional management strategy that allows for adaptation to changing conditions or unexpected outcomes and allows for follow through on successive phases of the institutional management plan.

In addition, to successfully transition to LTS, there are four characteristics that will increase the probability of a successful implementation of the LTS program. These characteristics are

1. Clear objectives and a desire on the part of those responsible for institutional management to carry out those objectives with diligence over time

2. A clear system of governance that specifies what is to be done and by whom and is founded on precepts that are enduring on the one hand and flexible on the other

3. An integrated overall approach that coordinates activities across the responsible entities and ensures that site management measures are complementary rather than conflicting

4. Incentives both within and outside the institutional management organization to encourage diligence in carrying out mission objectives. 


\subsection{LTS Transition Development}

Numerous existing documents and previous examples of facility transfer were investigated for developing transition criteria guidance. The most applicable of these was documentation/examples from the Formerly Utilized Sites Remedial Action Program (FUSRAP) site transition to DOE, and Technical Guidance for Reviewing Site Transfer Documents for Long Term Stewardship (DOE 2001b).

Additionally, documentation was reviewed from Department of Defense Base Realignment and Closure (BRAC) facility reuse and economic development projects, DOE facility transfers for closure sites (e.g., Mound), Nuclear Regulatory Commission license termination regulations, exit strategies for CERCLA, Department of Defense and DOE land use institutional control policies, federal natural resource management agencyprocesses, Bureau of Land Management, and U.S. Forest Service.

The criteria for transfer of a proposed management unit to LTS at the completion of other EM missions should be flexible enough to allow for transition of a unit that may be simple or complex. Transition criteria also should allow the LTS program to meet its long-term goals of maintaining sites in a condition protective of human health and the environment without significant additional remediation or monetary investment outside of those identified at the time of transition. Potential criteria for entry/exit from the LTS program may be unit specific (applicable to a particular tank, building, or operable unit); facility specific (risk or performance based); or capability or ecosystem management (e.g., flood control, roads, power). For long-term stability of completed EM missions (data and structures) and overall success of LTS, transition criteria should not be significantly different whether the transfer is within DOE or between DOE and an outside agency/organization.

The criteria identified in this report are intended to establish an exit point from other EM programs to the LTS program; the criteria do not define the exact end state. The criteria were derived from various existing guidance documents listed in the bibliography. Several other land transfer/transition examples, many having environmental legacies from past land uses, and LTS examples also were investigated for their application to development of the generic criteria:

- $\quad$ Transfer of other federal lands (non-DOE examples such as the Department of Defense BRAC to other agencies or the private sector

- $\quad$ Transfer of FUSRAP sites from the Army Corps of Engineers to DOE

- $\quad$ Experience gained by DOE in managing remediated uranium mill tailings sites.

\subsection{Transition Guidance}

Transition of sites to the LTS program will be negotiated between EM program and the existing site landlord Program Secretarial Office. Because multiple EM programs are likely represented within any given management unit proposed for transfer, these negotiations are expected to occur at the Deputy Assistant Secretary level. As a basis for initiation of transition negotiations, the basic types of criteria that must be satisfied prior to transfer include

- $\quad$ Regulatory - Statuary/regulatory-based requirements for cleanup and long-term performance

- Infrastructure-Infrastructure such as caps, wells, roads, equipment, etc., necessary to conduct LTS activities

- Data—Data and information of sufficient type and condition for LTS activities to continue 
- Scope, schedule, and budget - A defined project scope, contractual arrangement if required, staff support and field operations, schedule of LTS activities, and budget based on cost estimates

- Unique expertise or training required to conduct long-term operations

- Interface agreements to define responsibilities before and during transition, and after transition in the event a particular remedy fails or new releases occur from the unit.

\subsubsection{LTS Management Unit}

The size and scope of the proposed LTS management units is dependant on multiple technical, regulatory, economic, social, and political factors. A proposed LTS unit may include facilities or media being cleaned under CERCLA, RCRA, D\&D\&D, underground storage tank, or other regulations. It is assumed that the size and scope of the proposed LTS unit will be based on negotiations between the programs involved. While some units (or subunits) may have completed parts of their cleanup mission, they may not be in a condition appropriate for transfer to the LTS program. This could be the result of incomplete records, regulatory issues, poor condition of equipment and facilities or because it may not be appropriate to split off sub-units for LTS when associated sub-units are still conducting active remedial activities.

\subsubsection{Regulatory-Based Transition Guidance}

Regulatory transition criteria are concerned with meeting requirements of statutorily based environmental compliance agreements. These are the requirements for completion of the EM mission and include items identified in the Code of Federal Regulations and DOE orders used to meet Atomic Energy Act obligations (e.g., DOE Order 435.1, "Radioactive Waste Management," and 5400.5, "Radiation Protection of the Public and the Environment"). The regulatory-based transition criteria are listed below.

- $\quad$ For CERCLA sites, results of the last five-year review indicate that the remedial action meets the requirements of the ROD. For example, the ROD requires that contaminant concentrations follow a given trend or are below given levels. The site may be transferred to LTS if monitoring data indicate that these requirements are met. If these data indicate any requirement is not met, the Environmental Restoration Program will retain the site.

- $\quad$ For RCRA closure sites, results of a review of project data and information indicate that the site meets post-closure requirements.

- $\quad$ Permits not necessary for the stewardship phase should be closed out prior to transfer to the LTS program.

- $\quad$ Management plans are current and have required regulator approvals. Management plans may include sampling plans, quality assurance/quality control plans, monitoring plans, etc.

- Establish conditions under which responsibility for the LTS unit would be returned to the original EM program. For example, detection monitoring or subsequent compliance monitoring (if needed) for units closed under RCRA/Hazardous Waste Management Act conducted by the LTS program may indicate the site does not meet performance standards and further cleanup may be required.

- The requirements of DOE Order 435.1 are met regarding performance assessment and composite assessment. 
- Any restrictions or covenants for title, deeds, property transfer documentation, are put in place prior to transition.

- The proposed LTS scope is within the scope of approved National Environmental Policy Act documentation.

\subsubsection{Infrastructure Needs Transition Guidance}

The criteria listed below focus on ensuring that the physical facilities associated with the proposed LTS unit are in operable condition to conduct required LTS activities. The primary emphasis associated with these criteria is that the condition of infrastructures is sufficient to allow smooth transition of the proposed site without additional financial investment by the LTS program.

- All required physical and administrative institutional controls are in good condition. Administrative controls may include rights-of-way, legal permission, etc. Physical institutional controls may include fences, signs, monuments, and other on-site engineered features to secure access to LTS sites.

- $\quad$ Perched water or aquifer monitoring wells, on-site monitoring equipment, and ancillary equipment are in good condition. Monitoring data and maintenance records have been reviewed to determine the condition of the wells and procedures are in place for conducting maintenance and monitoring performance of the equipment.

- $\quad$ Equipment, monitoring wells, structures etc., that are not necessary for the LTS phase have been removed/decommissioned in accordance with applicable requirements.

- $\quad$ All access and required utilities have been maintained for the site.

- $\quad$ Any leachate collection system, monitoring equipment, and ancillary equipment are in good condition. Review of leachate monitoring data indicates the system is functioning as designed.

- $\quad$ Engineered caps or covers are in good condition. Monitoring data or the results of five-year reviews indicate that the cap is performing in accordance with closure requirements or the ROD.

- $\quad$ Physical site boundaries have been located and are consistent with the legal description recorded with county authorities and required deed restrictions.

- $\quad$ Radioactive waste management safeguards in accordance with DOE Order 435.1 are in place.

\subsubsection{Data/Information Management-Based Transition Guidance}

It is assumed that no additional analytical data will be collected to complete transition of a proposed LTS unit. Rather, data collected at a proposed unit to fulfill regulatory agreements is sufficient, assuming they meet quality assurance/quality control requirements and have regulatory approval. It is also assumed that approved documentation (by regulatory authorities) is sufficient for transition. These criteria primarily emphasize the availability, accessibility, and retrievability of data and information. The following is a checklist for verifying that data/information sources contain the required information to transfer to LTS:

- $\quad$ The Environmental Restoration Information Repository contains all post-ROD CERCLA documentation and monitoring data. 
- $\quad$ Project files contain RCRA documentation and/or post-ROD CERCLA documentation, as appropriate. Monitoring data are present and readily accessible.

- $\quad$ Project files contain current management plans (sampling, quality assurance/quality control, monitoring plans, etc.).

- Data and information necessary for LTS are identified and documented, and the data types are defined. A review of these data and information is conducted to confirm retrievability and accessibility and procedures exist to collect the required data.

- Monitoring data and maintenance records have been reviewed to determine the condition of the wells and procedures are in place for conducting maintenance and monitoring performance of the equipment.

- $\quad$ Site documentation and project files present the residual contaminant source term, contaminant concentrations, location, and potential risks to human health and the environment.

- Data is in a format that can be incorporated into the LTS program

- All reporting requirements and expectations are communicated between applicable programs, other government agencies, and stakeholders.

- $\quad$ Site documentation and project files contain current as-built drawings of surface and subsurface site features, residual waste locations, engineered features, monitoring wells, and physical institutional controls.

- $\quad$ Required land use restrictions are properly recorded (i.e., county court house, Bureau of Land Management, other agencies).

- $\quad$ Listing of information related to accessing the site such as routes, gates, site ownership, points of contact, deeds, easements, rights of way and other pertinent information.

- Historical and archeological resources at or near the site are located and documented in accordance with federal and state statutes.

- $\quad$ Any ecological concerns that may require modification of LTS activities are documented.

\subsubsection{Scope, Schedule and Resources}

The primary emphasis associated with these criteria is scope, schedule, and resource plans developed to meet budgeting requirements at the time of transition. The types of information listed below should contain sufficient detail to allow for incorporation directly into a project baseline summary document.

- $\quad$ The scope, schedule, and estimated cost for future life-cycle asset management of the proposed LTS project are defined and documented.

- $\quad$ The proposed LTS scope is consistent with regulatory requirements (post-ROD monitoring plans, post-closure plans, etc.). 
- The future funding mechanisms or programs where out-year funds have been requested have been identified to include any required contractual vehicles (e.g., National Nuclear Security Agency).

- Identification of critical resources and personnel required to accomplish tasks for the project after transition takes place.

- A listing of baseline changes that have been approved or any new contracts or modifications necessary before transition takes place.

\subsubsection{Special Conditions}

Conditions may require unique actions by the LTS program such as: the presence of historical, cultural, archeological, and ecological resources at the site may create special conditions for the proposed LTS site or long-term performance requirements may have been satisfied.

- $\quad$ Any special historical or cultural/archeological resources are identified and documented and any reviews required of the condition of historical or cultural resources under stewardship have been completed.

- $\quad$ Primary and secondary site management contracts that may be needed to consider unique programmatic or performance requirements for LTS programs have been completed.

- Any special historical or cultural/archeological resources requiring special management activities are included in the scope and cost estimates.

- Any special ecological concerns such as management of threatened or endangered species are included in the scope and cost estimates.

- $\quad$ Special management conditions for sites within flood prone areas are documented and incorporated into management plans.

- $\quad$ The performance identified, if applicable, which when satisfied may no longer require stewardship oversight and monitoring, and the site can then be removed from the LTS program.

\subsubsection{Identification of Long-term Stewardship Transition Guidance}

Appendix A gives guidance on data, information, and documents that may be required as cleanup of sites, regulated units, equipment, and engineered structures is completed and the sites are targeted for transition to the site's stewardship program. This table is not considered all-inclusive. It is designed as an aid in drafting local stewardship procedures and criteria.

\section{RECOMMENDATIONS FOR DEVELOPMENT OF TRANSITION CRITERIA}

Several recommendations are identified to further develop the transition criteria.

- $\quad$ Processes and/or procedures for transition of a proposed unit to the LTS program must be developed. The proposed criteria in this report are based on the assumption that specific processes or procedures will be put in place that guide project managers in preparing for transition of a proposed site to the LTS program. At a minimum the following must be performed: 
- $\quad$ A technical planning document must be developed establishing the current LTS operating baseline and describing the scope and operating costs for future LTS activities.

- The budget authority and budget target has been transferred to the receiving PSO of the amount equivalent to the operating costs for LTS activities.

- $\quad$ A formal transfer agreement for the LTS, that includes post-transfer responsibilities, has been coordinated and signed for each site.

- The current processes for information storage and retrieval of all EM programs should be researched as a basis for development of procedures for data and information repositories. As stated previously, one of the critical issues with the LTS program is handling of data and information. This issue will be crucial to smooth transition and future management of a proposed LTS unit.

- $\quad$ The Environmental Restoration Program must manage data and information associated with cleanup and post-ROD management. Procedures, guidance and records generated and written at the project management level will allow for efficient retrieval of project documentation.

- $\quad$ The D\&D\&D Program should maintain records of all project plans and schedules. These plans should show the interaction of the project with Environmental Restoration, Waste Management, and the Site Landlord Programs

- $\quad$ Site Landlord/Infrastructure Programs should maintain records of all projected land use planning and infrastructure requirements for all facilities. All land use and facility plan schedules should be retrievable by future stewards.

- $\quad$ The Waste Management Programs, high-level and low-level waste, must have all RCRAclosure documentation including post-closure permits and clean-closure documentation and all existing permits prior to RCRA closure or transition of operating equipment required for closure.

- $\quad$ Guidance must be developed for LTS cost estimates. It is generally recognized that cost estimates for projects with life cycles many years or decades into the future may require unique assumptions that are not normally used in shorter-term estimates. Estimates for proposed LTS units should also be standardized and consistent so that opportunities for long-term cost savings and duplicate costs can be identified.

- Guidance should be developed on assessing the condition of physical assets (e.g., monitoring wells, caps, and fences) associated with proposed LTS units. As units are proposed for transition to the LTS program, an evaluation would likely be conducted to determine the useful life of the wells in addition to replacement costs, which could be incorporated into LTS cost estimates.

- As a first step in development of transition processes, a site that is expected to be part of the LTS program could be evaluated. The above-proposed criteria would be used to evaluate the site and to determine whether procedures currently in place are adequate to provide a smooth transition of project data and information.

These guidance steps will assist the U.S. Department of Energy in: (a) ensuring that the long-term stewardship program leads transition planning with respect to facility and site area end-states, and (b) 
describing the classes and types of criteria and data required to initiate transition for areas and sites where the facility mission has ended and cleanup is complete. 


\section{REFERENCES}

40 CFR 280

DOE O 435.1, 2001, “Radioactive Waste Management,” U.S. Department of Energy, August 28, 2001.

DOE O 5400.5, 1993, "Radiation Protection of the Public and the Environment,." U.S. Department of Energy, January 7, 1993.

DOE Office of Environmental Management, 2001, Long-Term Stewardship Information Center: Law and Policy, http://lts.apps.em.doe.gov/center/stewlink0.asp, Web page updated August 9, 2001, Web page visited September 26, 2001.

DOE Office of Science and Technology, 2001, Office of Science and Technology: Our Mission and Function, http://apps.em.doe.gov/ost/aboutmissionfunction.pdf, Web page visited September 26, 2001.

DOE, 1998, Accelerating Cleanup: Paths to Closure, U.S. Department of Energy, Office of Environmental Management, DOE/EM-0342, February 1998.

DOE, 1999, From Cleanup to Stewardship, A Companion Report to Accelerating Cleanup: Paths to Closure and Background Information to Support the Scoping Process Required for the 1998 PEIS Settlement Study, DOE/EM-0466, DOE Office of Environmental Management, October 1999.

DOE, 2000, Status Report on Paths to Closure, Department of Energy, Office of Environmental Management, DOE/EM-0526, March.

DOE, 2001a, A Report to Congress on Long-Term Stewardship, Volumes I: Summary Report and Volume II: Site Summaries, DOE/EM-0563, U.S. Department of Energy Office of Long-Term Stewardship, January 2001.

DOE, 2001b, Technical Guidance for Reviewing Site Transfer Documents for Long Term Stewardship.

Glauthier, T. J., 2000, Department of Energy, to All Departmental Elements, Department of Energy, December 15, 2000, "Long-Term Stewardship Transition to Site Landlord," ES2000-026689.

House of Representatives, 1999, National Defense Authorization Act for Fiscal Year 2000 Conference Report--to Accompany S. 1059, Report 106-301, August 6, 1999.

Huntoon, Carolyn L., Department of Energy Environmental Management, to Distribution, January 19, 2001, "Long-Term Stewardship Responsibility."

INEEL, 2001, Long Term Stewardship Draft Technical Baseline, INEEL/EXT-2001-013133, September 28, 2001.

National Governor's Association, 2001, Long-Term Stewardship in the Nuclear Weapons Complex: LTS Selected Annotated Bibliography, http://ndep.state.nv.us/lts/biblio.htm\#key, Web page update April 2001, Web page visited September 26, 2001.

NRC, 2000, Long-Term Institutional Management of U.S. Department of Energy Legacy Waste Sites, National Research Council, National Academy Press. 
NUREG-1573, 1997, "Performance Assessment Methodology for Low-Level Radioactive Waste Disposal Facilities," U.S. Nuclear Regulatory Commission, 1997. 


\section{BIBLIOGRAPHY}

The following documents were used in determining transition criteria for long-term stewardship.

Association of State and Territorial Solid Waste Management Officials, 2001, "Federal Facility Managers Symposium, Meeting Agenda and Notes," Environmental Challenges at Federal Facilities: Past, Present, and Future, June 18, 2001.

DOE, 1999, Long-Term Surveillance and Maintenance Program Plan, GJO-99-93-TAR, Department of Energy, Grand Junction Office, June 1999.

DOE, Office of EPA (EH-41), to Distribution, DOE, October 18, 1999, "EPA Guidance on Transfer of Federal Property Undergoing CERCLA Remedial Action,” DOE F 1325.8(8-89).

DOE, 2000, Environmental Restoration-Offsites: Salmon Site, Mississippi, U.S. Department of Energy, Nevada Operations Office, Office of Public Affairs and Information, DOE-NV-589, January 2000.

DOE, 2000, Final Environmental Assessment for the Transfer of the Department of Energy Grand Junction Office to Non-DOE Ownership, DOE/EA-1338, U.S. Department of Energy, Grand Junction Office, Colorado, April 2000.

DOE, 2000, Status Report on Paths to Closure, U.S. Department of Energy, Office of Environmental Management, DOE/EM-0526, March 2000.

DOE, 2001, Environmental Quality, and Stewardship, http://www.inel.gov/x-web/other/framed.shtml?http://www.energy.gov, U.S Department of Energy Office of Environmental Management, Web page visited August 16, 2001.

DOE, 2001, Draft Interim Policy for the Department of Energy's Use of Institutional Controls, January 2001.

DOE, 2001, Long-Term Stewardship Case Study Report, U.S. Department of Energy, Office of LongTerm Stewardship, Final Draft, June 2001.

DOE, 2001, Long-Term Stewardship, Issue 01, Volume 01, Long-Term Stewardship Program INEEL, Idaho Falls, ID, July 2001.

Department of Defense, 2001, Using Environmental Insurance in DoD Property Transfers: A New Tool for Managing Cleanup Risk, BRAC Environmental Program Fact Sheet, Office of the Deputy under Secretary of Defense (Environmental Security), April 2001.

Department of Energy Office of Environmental Management, 2001, EM HQ Programs, Planning and Execution, and Laws and Regulations, http://www.em.doe.gov/index4.html, Web page updated July 24, 2001, Web page visited August 14, 2001.

Edge, Russel Pavelka-Zarkesh, Document Systems for Site Stewardship at the U.S. Department of Energy Grand Junction Office, Department of Energy Grand Junction Office, Colorado, MACTEC Environmental Restoration Services.

English, C. Joseph, and Jeffery Short, Presentation: "Estimating the Cost of Long-Term Stewardship of Environmental Restoration Sites," Project Performance Corporation. 
Environmental Law Institute, 2001, The Role of Local Government in Long-Term Stewardship at DOE Facilities, Washington, D.C., Environmental Law Institute.

INEEL, 2001, Environmental Management and Environmental Stewardship, http://www.inel.gov/, Web page updated July 27, 2001, Web page visited August 13, 2001.

INEEL, 2001, Environmental Restoration Long-Term Stewardship Program Plan (Draft), Idaho National Engineering and Environmental Laboratory, INEEL/EXT-2000-01108, Revision B, February 2001.

Office of the Under Secretary of Defense, DOD, to Assistant Secretaries of the Army, Navy, Air Force, and Deputy Under Secretaries of Defense-Environmental Security, Industrial Affairs and Installations, and Director, Defense Logistics Agency, July 25, 1997, "Responsibility for Additional Environmental Cleanup after Transfer of Real Property."

Phillippe, CA, Stan, ASTSWMO Federal Facilities Subcommittee, to Pat Rivers, ACOE HQ, Environmental Division CEMP-R, and David Geiser, Office of Long-Term Stewardship, Department of Energy, April 13, 2001.

Quale, Ted, 2001, Presentation: “Mound Long Term Stewardship Initiative,” BWXT of Miamisburg, Ohio, August 1, 2001.

Smith, P. J., 2001, Idaho National Engineering and Environmental Laboratory Long-Term Stewardship Program Strategic Overview, Revision 0, July 11, 2001.

Starck, Robert A., DOE Idaho, to Ms. J. M. Crisler, Advisory Council on Historic Preservation, July 26, 2001, "Memorandum of Agreement for the Proposed Dismantlement of Historic Idaho National Engineering and Environmental Laboratory Properties (TS-ETSD-01-146)." 


\section{Appendix A}

\section{Example Documentation to Identify LTS Transition Criteria}


A-2 


\section{Appendix A}

\section{Example Documentation to Identify LTS Transition Criteria}

\author{
Criteria Type
}

\section{Completion of Cleanup Action - End-State Attainment and Remedy Performance Assessment}

Baseline description of site or units undergoing transition - terminology consistent with other transition criteria documents.

Construction Completion Report (CCR) (or equivalent under RCRA, if applicable).

Documentation of Agency and Stakeholder concurrence with CCR.

Site performance assessment - including dose assessment per DOE EPA/Guidance for DOE Order 435.1, NUREG - 1573 Performance Assessment Methodology for Low-Level Radioactive Waste Disposal Facilities (and other dose/risk assessment references as applicable).

CERCLA Administrative Record and RCRA Equivalent.

Information gained from review of Institutional Control Plans and any annual inspection/ surveillance.

\author{
Rationale
}

The demonstration of cleanup completion and end state attainment is the underlying basis for a site or unit to transfer from EM or equivalent cleanup responsible party, to the LTS or PSO for LTS management.

Life cycle cost estimation and site specific LTS implementation planning.

Demonstrates transition from EM to LTS or PSO can occur.

Litigation support.

If the analyses are applicable to a given site, they should demonstrate with reasonable assurance that the exposure to humans from any radiological release will not exceed acceptable limits.

Litigation support. Technical information repository.

The demonstration of cleanup completion and end state attainment is the underlying basis for a site or unit to transfer from EM or equivalent cleanup responsible party, to the LTS or PSO for LTS management. 


\section{Site Hazards and Characterization Information}

\section{A. Transfer of Data and Information Regarding Existing Hazards}

Historic groundwater, air, soil, vegetation, climatological, and related

monitoring/characterization data.

Monitoring well type, status, construction, completion reports, geospatial data, intent or basis for installation.

Validated life-cycle cost estimates for operation and maintenance (O\&M) of ground water, air, soil, vegetation and other monitoring networks.

Characterization data and source term calculations for low level, hazardous and mixed wastes disposed of on-Site and off-Site.

Reports depicting pre-ROD, pre-post closure permit risk analyses, fate and transport modeling in support of CERCLA ROD, subsequent remedial design/remedial actions, RCRA corrective measures, Consent Order compliance measures, etc.

The Remedial Investigation/Feasibility Study documentation.

\section{B. Documentation for Past and Present Releases - Normal Operations and Accident Conditions}

Available records for historic air shed monitoring, stack test and monitoring data.

Spill-reporting records and chemical use reporting under SARA Title 311 through 313.
Establishes the basis for need to conduct remedial/corrective actions and baseline for design of remedy selection and design. Basis for trend analysis. RCRA facility groundwater compliance determinations. Basis for risk analysis or decision process to not performing remedial actions.

To aid in trend analysis, refinement, and verification of models. As an aid in modifying existing well network, repair/rework of existing wells.

Serves as the basis for responsible budget requests and allocation throughout the LTS program.

Radiological and hazardous materials source term knowledge critical for emergency response and contingency planning involving buried waste, engineered landfills entombed structures. Litigation support. New information, models, understanding of contaminant hazards may make location and amount of residual important for later risk assessment and abatement.

To aid Stewards in reconstructing remedy selection and evaluation via five-year ROD reviews and equivalent under a RCRA post closure permit or RCRA corrective action. To aid in trend analysis, refinement and verification of models.

Source of characterization data and source term calculation.

Establish site baseline and/or for trend analysis. Detection of remedy failure or breach of containment in engineered structures. Epidemiological studies. Ecological risk and impacts to receptors studies.

Supports possible litigation, exposure reconstruction, epidemiological studies. 


\section{Transfer of Data, Information and Records Relative to Disposition of Historical Hazards}

Individual D\&D project characterization plans, Decision Analysis Reports, Decontamination and Decommissioning Plan, D\&D Data Packages, Independent Verification Contractor (IVC) reports, project-specific site or facility release criteria, "institutional controls" including need for ongoing monitoring of structures, soils, groundwater (e.g. Hanford C-reactor and INEEL's Borax V reactor entombment).

Waste analyses, performance assessment sampling, source term calculations other data in support of RCRA clean closed or successful risk based closure determinations. Independent registered Professional Engineer certification of closure.

Nature and disposition of residuals remaining in place from waste treatment, RCRA closure and CERCLA remedial actions.

Regulatory agency approvals of closure and corrective measure implementation efforts. Registered Professional Engineer certifications and reports for RCRA closures and corrective measures implementation.

\section{Site Pollution Prevention, Storm Water Runoff, Emergency Preparedness/Contingency Planning (EP/CP)}

Active $\mathrm{P}^{2}$ plans for pollutants generated via the remedy (waste treatment residuals) and LTS supporting infrastructure (labs, vehicle fleet).

Storm Water Runoff Plans.

Spill Prevention Control and Countermeasure Plan.

Site-specific EP/CPs.
Enables the LTS and stewards to determine what was done, why it was done, anticipated risks, and basis for whether or not a project site should undergo corrective measures based upon monitoring trends, revised risk calculations, technological improvements in D\&D processes. Lessons learned may be of value to D\&D-like activities, when much of the site is otherwise well into the stewardship mode. For example, an high-level waste (HLW) Vitrification Plant at the INEEL may operate up to approximately 2050 , long after much of the INEEL will be in the surveillance and maintenance mode.

Identifies to the LTS the residual hazards site baseline, including hazards source term, thereby providing the stewards the basis for end state, basis for observing trends or changes observed contaminant levels. Ongoing legal record of end state attainment.

New information, models, understanding of contaminant hazards may make location and amount of residual important for later risk assessment and abatement.

Litigation support. Land or real property transfer support.

Compliance with the resource conservation and recovery provisions of the RCRA.

If invoked for long-term O\&M of landfill caps, access roads, etc.

For any on-site petroleum products in excess of threshold planning quantities.

Emergency response may be the responsibility of multiple entities, such as the site LTS Contractor, as well as Tribal nations, Local, and State entities. 
DOE Groundwater Protection Program Plans.

Memoranda of Understanding between DOE, Tribal nations, Local and State emergency management organizations.

Life-cycle cost estimation for DOE financial support to Tribal, Local and State emergency management organizations.

\section{E. Transfer of Information Regarding Existing Barriers and Other Active or Passive Remediation Measures}

Landfill cap and leachate collection operational boundaries, design, and as-built drawings.

Reactor entombment project files (outside RCRA or CERCLA purview).

Grouted facilities design, instrumentation and sensors verifying integrity and source term containment.

Validated life-cycle cost estimate of O\&M costs.

\section{Operations and Activities}

\section{A. Process History}

Manifests and bills of lading for waste disposed of on-Site and off-Site (not releases).

Waste inventory tracking in RCRA and CERCLA disposal units. Location, geographical information system (GIS), survey data, volume, radiological and chemical characteristics of waste in engineered cells.

Key project personnel.
Implement on-going ground water monitoring program per DOE 5400.1.

To facilitate timely and credible emergency response.

Training, documentation, and equipment.

Operational limits per ROD, or Post-Closure Permit, lessons learned, technology evaluation. An aid in surveillance and maintenance efforts, emergency response, retrieval actions, investigation and mitigation of apparent releases.

To aid in surveillance and maintenance efforts, emergency response and preparedness, retrieval actions, investigation and mitigation of apparent releases.

To aid in surveillance and maintenance efforts, emergency response, lessons learned, technology evaluation, retrieval actions, investigation and mitigation of apparent releases. RCRA post-closure permit compliance.
Material accountability. Litigation support.

To provide source term data for explaining trends in monitor well analyses, anomalies in leachate collected in engineered leachate collection systems. To aid Stewards with responsibilities for long-term surveillance and maintenance activities. To aid Stewards with emergency response planning - such that breaches of containment can be managed with the extent of hazards known.

Litigation support, epidemiological studies, project reconstruction, release history. 
Waste inventory tracking in nonhazardous industrial landfills.

Chemical and radiological material types and quantities used in research and development and normal DOE mission activities (non-waste management activities).

\section{B. Historical Infrastructure}

Facility utilities, facility design and as-built drawings.

Utility performance parameters (power grid capacity).

Archival photographs, including aerial photographs, GIS representation of site conditions.

\section{Regulatory Compliance}

\section{A. Regulatory Framework - Past and Present}

Relevant environmental permits, licenses and authorizations. Records pertaining to enforcement actions.

Applicable regulations in effect throughout the preLTS and LTS life-cycle.

Comprehensive NEPA documentation or equivalent determinations under CERCLA.

\section{Requirements Specific to Transfer/Closure and Post-Closure Transfer}

\section{Real Estate Records}

Records indicating property leases and historic public access.

Memoranda of Understanding Between DOE and other Agencies for DOE use (e.g., BLM).

Title and deed records .
In the event they appear to pose a release threat eventually. Post-closure land use information for siting new facilities.

Release investigation, dose reconstruction, litigation support.

Economic redevelopment, reuse, facilitation of D\&D.

Economic redevelopment, reuse, facilitation of D\&D.

Litigation support. Emergency response support. Cultural and ecological resource management support. Land transfer support.

Ascertain on-going ROD, post-closure permit compliance, and assist in determining life-cycle funding needs.

Compliance determinations, litigation support.

Overall NEPA compliance, including cumulative impact analysis of long-term remedy implementation.

Responsibility for impacts, epidemiological studies, litigation support.

Facilitation of transfers, permanent withdrawals, economic development efforts.

Property release, economic redevelopment, litigation support. 


\section{Active Remedial Action Design and} Operating Data Information

FFA/CO Post-ROD five-year review findings of remedy effectiveness, Operations and Maintenance records, and Institutional Control Plan performance determinations.

On-going trend analysis of groundwater, vadose zone contamination evaluation.

\section{Nuclear Materials Accountability}

Records demonstrating recovery of nuclear materials, such as fissile materials, and sealed sources from nuclear fuel processing plants.

Key project personnel.

\section{Subsurface Phenomena Research, Science and Technology}

Research and development findings, refereed journals.

Enhanced surveillance and instrumentation techniques.

In situ contaminant management findings.

\section{Historic and On-Going Agreements}

\section{A. RODs, Post-Closure Permits, NON/COs}

B. Agreements Related to DOE's Cultural, Historic and Ecological Resource Responsibility

Validated lifecycle O\&M Cost Estimate of natural resource and ecology stewardship activities.

Management of eligible and State/Nationally designated historic sites.

DOE and Tribal Nations Agreements
ROD, O\&M, and IC plan compliance and effectiveness.

Remedy completion determination. Property release or limited reuse evaluation.

Support safe closure, end state attainment and surveillance of grouted/entombed facilities. Dose reconstruction. Litigation support. National security.

Operational history reconstruction, lessons learned, litigation.

Continued improvement, substitution of remedial technologies, advance sensor development.

Continued improvement, release detection, remedy evaluation.

Continued improvement, substitution of remedial technologies.

Enforcement and litigation support.

Enforcement and litigation avoidance and general resource protection. Facilitation of land/real property transactions.

Declaration of funding and compliance liability.

Stakeholder relations. Specific agreements related to cultural and ecological resources. 
Any natural resource management plans or agreements including any Memorandum of Understandings (MOUs) or Memorandum of Agreements (MOAs).

\section{Stakeholder Involvement Documentation}

Public Involvement Plans and stakeholder/DOE comment/response documentation.

Transcripts from stakeholder meetings.

\section{Custodial Agreements}

Memoranda of Understanding between DOE, Local, State, and private sector entities.
Ascertain obligations for long term management.
To facilitate emergency response actions, land transfer actions, Brownfields development, and economic redevelopment efforts. 